\title{
Policy Options to Remove Export Barriers Encountered by Indonesian SMEs
}

\author{
Mohamad Dian Revindo ${ }^{\mathrm{a}, \mathrm{c}, *}$, Sri Mulyani Indrawati ${ }^{\mathrm{b}}$, \\ \& Natanael Waraney Gerald Massie ${ }^{c}$ \\ ${ }^{a}$ Graduate School of Global and Strategic Studies, Universitas Indonesia (SKSG UI) \\ ${ }^{b}$ Department of Economics, Faculty of Economics and Business, Universitas Indonesia (FEB UI) \\ ${ }^{c}$ Institute for Economic and Social Research, Faculty of Economics and Business, Universitas Indonesia \\ (LPEM FEB UI), Jakarta
}

\begin{abstract}
Indonesian SMEs are less able to take advantage of free trade and globalization than their large counterparts, contributing only a small share of non-oil and gas exports. This study investigates the export barriers faced by SMEs. Primary data was obtained from survey questionnaires to SMEs in seven provinces in Java, Madura and Bali regions and central government agencies whose policies are related to SMEs and/or international trade. The survey yielded 533 usable responses, including 271 exporting SMEs, 226 non-exporting SMEs and 36 central government agencies. The findings show that the effectiveness of export assistance programs vary across types of assistance and levels of government. Further, policymakers and SMEs had different perceptions on the severities of each type of export barrier. The practical implications of the findings are provided.
\end{abstract}

Keywords: SMEs; internationalization; export barriers; export assistance; Indonesia JEL Classification: F23; L25; M13; M16; O17

${ }^{*}$ Corresponding Author: Institute for Economic and Social Research - Faculty of Economics and Business - Universitas Indonesia (LPEM FEB UI), Jl. Salemba Raya No. 4, Jakarta 10430, Indonesia. E-mail: revindo@lpem-feui.org. 


\section{Introduction}

In the midst of latest developments in trade liberalization, local companies are compelled to contend with comparatively better imported products and the multinationals (Awuah \& Amal, 2011; Knight, 2000; Ruzzier et al., 2006). However, greater participation in international business activities has been apparent in recent centuries (Welch \& Luostarinen, 1999), i.e. enhanced export, import, foreign exchange, leasing, as well as cross-border collaboration (Calof \& Beamish, 1995; Ruzzier et al., 2006). Vivid examples include the facts that world merchandise export value has more than tripled in 2001-2014 (ITC, 2016a), global services exports experiencing a similar 3.5-fold increase (ITC, 2016b), world foreign direct investment (FDI) outward stock increase by more than 3.3 times (UNCTAD, 2014, 2015), along with the increased trade openness contributing for the sustainability of businesses' growth and productivity (OECD, 2012) - all despite the global economy being hampered by the 2007-08 global financial crisis.

While the benefits of the phenomenon have been well documented, it may be difficult to argue that such gains have been reaped equally among countries and enterprises. Such inequality can be observed across two levels, with the first being observed at cross-country level. As reported by ITC (2016a), 56 to 60 percent of the global merchandise export value was attributed to the 34 OECD member states. As the fact raises several questions on the ventures of the developing countries in utilizing the opportunities provided by the liberalization, another pressing discrepancy is also observable at the business level. Numerous studies have pointed out that SMEs' contributions in the internationalization are modest at best (Adlung \& Soprana, 2013; Dalli, 1995; Kogut \& Chang, 1996), and are less likely to engage in outward FDI and/or service exporting activities (Adlung \& Soprana, 2013; Breinlich \& Criscuolo, 2011; Hollenstein, 2005; OECD, 2012). For instance, in the mid-2000s SMEs in the US, the Nethernalds, China, Japan, Switzerland, and the United Kingdom only contributed 30 to 38 percent of their respective national exports (Hammer \& Stamps, 2010).

Such occurrences do not elude the developing countries. In fact, the figures are worse-SMEs only accounted for 23 percent of the total value of export in ASEAN member states (Wignaraja, 2012). ${ }^{1}$ As such, this study focuses on Indonesia, one of the above-mentioned developing countries. In particular, we aim to analyze the internationalization of Indonesian Small and Medium-sized Enterprises (SMEs). The text discusses three aspects relating to the country's direct export activities. First, we are exploring the export barriers encountered by such enterprises. Second, we would describe the pertinent policymakers' perspectives on such barriers. Third, we formulate appropriate policy recommendations that

\footnotetext{
${ }^{1}$ The Association of Southeast Asian Nations (ASEAN) is a regional economic and political cooperation organisation among Southeast Asian countries. ASEAN was founded in 1967 and currently comprises ten member states namely Indonesia, Malaysia, Philippines, Singapore, Thailand, Brunei Darussalam, Viet Nam, Lao PDR, Myanmar, and Cambodia.
} 
we consider necessary to promote the export given that SMEs and policymakers' identification of the main export barriers are likely to differ.

The relevance of the study may not be understated. SMEs' inability to exploit the gains from free trade may indicate that such enterprises face different challenges and even greater impediments compared to their larger, more mature counterparts. Paying attention on these SMEs is crucial (Hollenstein, 2005; Hymer, 1976; Onkelinx \& Sleuwaegen, 2008), as the smaller firms have particular characteristics, i.e. their small size and limited resources, which might prove to be detrimental on their internationalization exploits (Laghzaoui, 2007; Ruzzier et al., 2006). Moreover, the greater degree of difficulty faced in internationalization by SMEs from emerging nations could not be disregarded. This particular study of Indonesian SMEs, in turn, would probably contribute to our understanding of SME internationalization in emerging countries in the face of increased involvement in various Free Trade Agreements (FTAs). ${ }^{2}$

Further delving into the Indonesian context, it is important to note that during 2005-13 SMEs accounted for an immense 99.99 percent of the country's business entities, providing more than 97 percent of job opportunities and 56 to 59 percent of GDP (Ministry of Cooperatives and SMEs Republic of Indonesia, 2009b, 2010a, $2010 b, 2013,2014 a, 2015)$. Such important role ${ }^{3}$, however, was juxtaposed with the miniscule contribution of the SMEs. In 2005-07, the enterprises' share in Indonesia's non-oil and gas exports was reportedly 18.5 percent, while the next couple of three years period saw a decrease to 16.9 percent and 15.4 percent respectively. ${ }^{4}$ Above-mentioned facts suggest that SMEs in the country are less able to take advantage of export opportunities than larger companies (Wengel \& Rodriguez, 2006). Furthermore, surveys indicate that such SMEs fared worse than most other ASEAN nations (Wignaraja, 2012) and, trivial, developed countries (Hammer \& Stamps, 2010). These issues continued amid the government's multiple strategy initiatives such as overall aid (e.g. loan entry, technical and management preparation) and export-related aid (e.g. trade recognition, company pairing, among others).

Since SMEs face complicated export challenges, the efficacy of policies and assistance related to exports needs a thorough understanding of the export operations of SMEs. As for Indonesia, while comprehensive research has been carried out on the small and medium-sized enterprises of the country, only few

\footnotetext{
${ }^{2}$ In August 2016, Indonesia had eight FTAs in effect, including ASEAN (1993), ASEAN-China (2010), ASEAN-Australia and New Zealand (2010), ASEAN-India (2010), ASEAN-Japan (2008), ASEAN-Korea (2007), Indonesia-Japan (2008), Indonesia-Pakistan (2013). Indonesia also has ongoing negotiations with several other regional and bilateral FTAs.

${ }^{3}$ Prior to the implementation of the Law No. 20 (2008) on Micro, Small and Medium-Sized Enterprise, the "Small-sized Enterprise" term generally included small and micro-enterprises.

${ }^{4}$ If oil and gas exports are included, SMEs' and micro-enterprises' contribution might be even lower since oil and gas exports are performed by large state-owned enterprises. Hence, this figure supports Wignaraja (2012) that Indonesian SMEs' contribution to total exports was actually 9.3 percent.
} 
shed light on their internationalization, especially their export activities. Of these few research, a rather comprehensive study was made by Revindo (2017) who looked at the stimuli, barriers, strategy, process, determinants dan impact of SMEs internationalization. Other studies only addressed particular and isolated internationalization problems, for instance, the role of human capital (Sari et al., 2008), export stimuli (Revindo \& Gan, 2016), export performance (Wengel \& Rodriguez, 2006), the impact of trade facilitation programs (Tambunan, 2009b) the impact of sector clustering on exports (Tambunan, 2009a), export barriers typology (Revindo, 2018) and export strategy (Revindo et al., 2017).

Moreover, most of the extant literature has partially looked at SMEs in certain regions, sectors or industries in Indonesia. For instance, Sari (2011) examined the internationalization of manufacturing companies while Jane (2013), Zubadi and Nugroho (2012) and Roida and Sunarjanto (2012) examined the case of firm internationalization in Bandung City, Magelang Regency, and East Java Province, respectively.

We argue that there are several distinctions that contribute to the particular topic between this paper and its predecessors. First, this study delves deep into the existing policies by examining the export assistance programs for SMEs provided by central, provincial and municipal government agencies. Second, to the best of our knowledge, this study is the first attempt to systematically identify the potential mismatches of perceived export barriers between the government as policymakers and the SMEs that may lead to the ineffectiveness of the export supporting programs. Third, we propose that - in combined with the previous coverage - the depth of assessment can greatly benefit policymakers in formulating general strategy and policy measures and managerial stakeholders in understanding the procedures, policies and challenges of internationalization.

The rest of the research is arranged as follows. After introducing the significance of the study in the continuing first section, our second chapter contains a review of the literature in question. We describe detailed overview of the methodologies used in this research in the third chapter. In the fourth, the findings of the research followed by the appropriate implications and policies debates will be presented, while the fifth will conclude.

\section{Literature Review}

This section focuses on the existing export barriers literature and their relationships with SMEs internationalization. Before further delving, we shall provide definitions about the terms used in the study. Export barriers can be defined as multiple barriers that impede the efforts of a firm to initiate, sustain or develop export activities (Leonidou, 1995, 2004). Among companies, the perception of such obstacles may dissuade internationalization, especially in the case of small and medium-sized businesses. Non-exporting companies may be unwilling to begin exporting because of such obstacles, while neophyte exporters may be prompted to withdraw from their early forays overseas. In addition, business 
sustainment and expansion of established exporters may also be halted. Minimizing obstacles, if not removing them, is therefore considered essential in pushing for business internationalization.

In effectively overcoming the barriers, such afflictions need to be meticulously identified, their level of intensity, as well as the severity (Leonidou, 1995, 2004). In this way, appropriate stakeholders at the managerial level can be more anticipative, thus decreasing the impact of these barriers on export activities. These countermeasures may prove to be important, especially for the more trivial problems that are easier to be coped with given appropriate preparations. Such excellent understanding may also help governmental agencies - appropriate policies and/or assistance can be eluded from ill-preparation.

The views in the existing literature on conceptualizing the export barriers are rather mixed. One research stream paid significant attention to identifying such barriers in the various export phases (see, for example, Bilkey \& Tesar, 1977; Leonidou, 2004; OECD-APEC, 2006). It was argued that barrier kinds and severity may vary across various export phases. The barriers at the pre-export point are usually based on the businesses' a priori, subjective perception and opinion rather than actual business experiences in the market. Most of these barriers are related to internal capacities and market opportunity identification. The companies are accumulating hands-on experience from daily foreign market ventures, moving on to the export level. For example, while one company may be more worried about the hostile business setting overseas, such opinions may change to relationship management with overseas distributors and clients as the firm becomes more experienced in trade activities.

The typology of export barriers is emphasized by a different stream of inquiries in this area. Examples include a wide range of export barriers related to internal and external export barriers (Leonidou, 1995, 2004). While the internal barriers comprise the export barriers deemed to be internal to companies (mostly related to the capability and availability of resources and production), the external barriers include those from the domestic and target market environment. An alternative approach is classified the barriers by national and foreign typology (Leonidou, 1995). Included in the domestic barriers are the lack of government support, underdevelopment of industries, and resource shortages. As for foreign barriers, there are stringent regulations, separate demands from customers, and distribution problems. There is also a combination of the two typologies (typologies internal-external and domestic-foreign). Such a combination includes internal-domestic (e.g. barriers to human resources), external-domestic (e.g. domestic company environments beyond the control of the company), internal-foreign (e.g. marketing strategy of the company in target markets) and external-foreign (e.g. foreign country regulations) (Leonidou, 1995). Table 1 below presents the most extensive typologies per Leonidou (2004) and OECD (2012) offer. 
Table 1: Typology of Export Barriers

\begin{tabular}{lll}
\hline Leonidou (1995) & Leonidou (2004) & OECD (2012) \\
\hline Internal Barriers & Informational Barriers & Informational Barriers \\
& Functional Barriers & Human Resource Barriers \\
& Marketing Barriers & Financial Barriers \\
& & Product and Price Barriers \\
& & Distribution, Logistics and Promotion \\
& Barriers \\
\hline External Barriers & Procedural Barriers & Procedural Barriers \\
& Governmental Barriers & Governmental Barriers \\
& Task Barriers & Customer and Foreign Competitor Barri- \\
& & ers \\
& Environmental Barriers & Business Environment Barriers \\
& & Tariff and Non-Tariff Barriers \\
\hline
\end{tabular}

The empirical evidence of the export barriers listed in Table 1 has been extensively documented, including those related to SMEs. On the internal side, inadequate global market knowledge and information may be the first issue for SMEs in attempting to initiate export. SMEs are often reluctant to start exporting due to the lack of reliable market location and analysis information, international market data, business opportunities and customer contact (EFIC, 2010; Hashim, 2012; Leonidou, 2004; OECD, 2009). Another internal barrier may arise in the form of functional barriers, including issues linked to the constraints that SMEs face in their funding, department of human resources, and manufacturing capacities. Human resource barriers include organizational and time inadequacies, restricted export staff, and little innovation (Freeman et al., 2006; Hashim, 2012; Köcker \& Buhl, 2007; Leonidou, 2004; OECD, 2008). Barriers to production include limited ability, unreliable input, and failure to develop fresh products (OECD, 2008; Tambunan, 2009a). Lack of working capital and limited access to finance for export activities are the financial barriers (EFIC, 2010; Freeman et al., 2006; Hashim, 2012; Köcker \& Buhl, 2007; Leonidou, 2004; OECD, 2008; Tambunan, 2009a, 2009b). In addition, marketing functions of SMEs may also remain weak in terms of appropriate product arrangements, pricing, logistics, distribution and promotion (Leonidou, 2004; OECD, 2008; Tambunan, 2009a).

Meanwhile, there are also well-documented external barriers faced by SMEs. Procedural barriers are associated with the customers ' operational elements, i.e. lack of familiarity with the appropriate processes, communication failures and slow collection of payments (Leonidou, 2004; OECD, 2008; Rahardhan et al., 2008). The actions of inaction by the home government are also crucial in the export activities of SMEs. The close and intensive facilitation by the home government may assist indigenous exporters, but such assistance is limited. Similarly, regulatory frameworks are often considered too sophisticated (Hashim, 2012; Leonidou, 2004; OECD, 2008; Wengel \& Rodriguez, 2006). In addition, SMEs are entrusted with coping with task barriers as distinct areas may consist of distinct customer and competition behaviors and/or attitudes (Hashim, 2012; Köcker 
\& Buhl, 2007; Leonidou, 2004; OECD, 2008). Foreign market environments may also interfere with trade activities in the form of decreasing country economic conditions, fluctuating exchange rates, political instability, rigid regulations and (non) tariff barriers (EFIC, 2010; Hashim, 2012; Leonidou, 2004; OECD, 2008; Rahardhan et al., 2008). There is also problem of environmental obstacles, i.e. distinct socio-cultural characteristics, unfamiliar company procedures and language (Köcker \& Buhl, 2007; Leonidou, 2004).

The study notes that the prior export barriers studies have concentrated more on developed countries instances. The lack of evidence from developing / emerging nations, especially Indonesia, leads the study to investigate these fronts. In addition, there was also a lack of export barrier research illustrating the possible differences in perceived export barriers between the business and the policymakers, leading to ineffective policy measures. Therefore, this study aims to help address the research gap.

\section{Method}

\subsection{Study Area and Data Collection}

This study focuses on small and medium-sized enterprises (SMEs) and excludes micro and large enterprises. ${ }^{5}$ Among the different definitions of SMEs, two definitions are widely used in Indonesia:

1. The Ministry of Cooperatives and SMEs defines SMEs as enterprises with assets valued at Rp50 million-Rp10 billion (equivalent to USD3,846.15USD769, 230.77) or with an annual turnover of Rp300 million-Rp50 billion (equivalent to USD23,076.9-USD3,846,153.8) ("Undang-undang No. 20 Tahun 2008 tentang Usaha Mikro Kecil dan Menengah [Law on Micro, Small and Medium-Sized Enterprise Number 20 of 2008].", 2008). ${ }^{6}$

2. BPS-Statistics Indonesia defines SMEs as enterprises with 5-99 employees (BPS-Statistics Indonesia, 2014a).

During the pilot survey, we found that it was difficult, laborious and potentially inaccurate at the practical level to identify the assets and turnover value of SMEs. Asset valuation of SMEs needs a complicated assessment technique and turnover estimates of SMEs are not always accessible due to improper bookkeeping. This study therefore refers to the definition of SMEs by number of employees (5 to 99) used by BPS-Statistics Indonesia. Despite its applicability, it is important to mention that there are also shortcomings in this concept. In particular, the SME definition by number of employees has potential bias towards capital-intensive industries. For instance, this concept possibly involves some

\footnotetext{
${ }^{5}$ Micro enterprises are excluded for two reasons. First, the micro enterprises database is unavailable in Indonesia as they are mostly in the form of individual businesses or home industries. Second, micro enterprises are less likely to engage in international business (Pendergast et al., 2008).

${ }^{6}$ The exchange rate is assumed at Rp13,000/USD.
} 
large-scale businesses in capital-intensive sectors that hire a tiny amount of staff, but excludes medium-sized businesses in labor-intensive sectors that hire big amounts of workers.

In Indonesia, the total number of SMEs was approximately 678,415 in 2012 (Ministry of Cooperatives and SMEs Republic of Indonesia, 2014b). However, SMEs in Indonesia are not fairly distributed across provinces/ regions. Approximately 60 percent of the country's SMEs are focused on only 3 islands; Java, Madura, and Bali (Kuncoro, 2009; Wiratno \& Dhewanto, n.d.). This imbalanced allocation of SMEs mainly represents the trend of financial agglomeration in Indonesia, which leads financial development to be mainly focused on those three closely related island. The three islands consist of only seven provinces and constitute only 7.07 percent of the country's total land area but are inhabited by 57.5 percent of the country's total population and generate over 58 percent of the country's total GDP/value added (BPS-Statistics Indonesia, 2014b).

Our research focuses on SMEs located in Java, Bali and Madura Islands, taking into consideration these agglomeration models of financial and SME activity in Indonesia. The three islands also have stronger transportation and communication infrastructure than the remainder of the nation, enabling easier connections to study a large amount of SMEs that are distributed across the islands within moment and budget constraints. The aim population of this research is therefore the SMEs operating in seven provinces on the coasts of Java, Madura, and Bali.

To construct the sample frame, we merged four different databases into one list of SMEs from which the samples were picked. The first three databases were published by the Ministry of Cooperatives and SMEs including: (1) the Ministry of Cooperatives and SMEs' online trading board"7 (2) SME and Cooperative Indonesia Catalogue (Ministry of Cooperatives and SMEs Republic of Indonesia, 2011, 2012) ${ }^{8}$; and (3) Exporting SMEs Directory book (Ministry of Cooperatives and SMEs Republic of Indonesia, 2009a) ${ }^{9}$. The fourth database is the Indonesian 2006 Economic Census provided by BPS-Statistics Indonesia. ${ }^{10}$

The calculated sample size is $384 .{ }^{11}$ However, to anticipate insufficiency and incomplete responses, the sample size was increased by at least 20 percent (to

\footnotetext{
${ }^{7}$ Online promotion at the website of the Ministry of Cooperatives ad SMEs, http://www. indonesian-products.biz.

${ }^{8}$ The catalogue provides SMEs' contacts and products description in four languages (English, Arabic, Japanese, and Indonesian). The catalogue is published annually as part of the ministry's promotion program.

${ }^{9}$ The directory books listed all SMEs that participated in international trade shows organised by the Ministry of Cooperatives and SMEs' during 2005-2009.

${ }^{10}$ The BPS-Statistics Indonesia (National Agency for Statistics) performs economic censuses every ten years. When the survey for this study was conducted in 2014, the most recent census was the 2006 national census while the next census will be conducted in 2016 and published in 2018.

${ }^{11}$ The population of SMEs in the study area $(\mathrm{N})$ is approximated to be around 407,049 (approximately 60 percent of the total Indonesian SME population of 678,415$)$. The sample (n) would not exceed 20,352 SMEs (5 percent of SMEs population in the study area) due to time and budget constraints. In the case that $n \leq 0.05 N$, the sample size formula for an infinite population is appropriate
} 
at least a total sample of 461). It is important that our study sample consists of SMEs in different export stages including exporting SMEs and non-exporting SMEs due to the changes and possible variations in export barriers across the export phases. However, stratified sampling was not applicable as the export status of the SMEs was unknown prior to the survey. Therefore, a quota random sampling method was used in which the sampled SMEs were drawn randomly from the sample frame until the export status category of each SME was filled in. As such, the survey targeted at least 192 samples (half the calculated sample size of 384) for each category of exporting and non-exporting SMEs (see Figure 1).

The study was administered with the assistance of qualified research assistants in April-August 2014. We contacted and approached 971 SMEs during the study era, 522 of whom were prepared to engage in the study (a response rate of 53.76 percent). As many as 449 SMEs refused to participate in the survey, had shut down the business or changed the number of employees beyond 5-99. Of the 522 questionnaires returned, 497 were valid, while 25 were unusable owing to unfinished answers. The available answers comprised of 271 exporting SMEs and 226 non-exporting SMEs and therefore achieved the desired complete sample size and quota. Furthermore, in the category of 226 non-exporting SMEs, 114 SMEs had the intention and plan to export and the other 112 had no intention of exporting in the future, which added more variation to the sample collected.

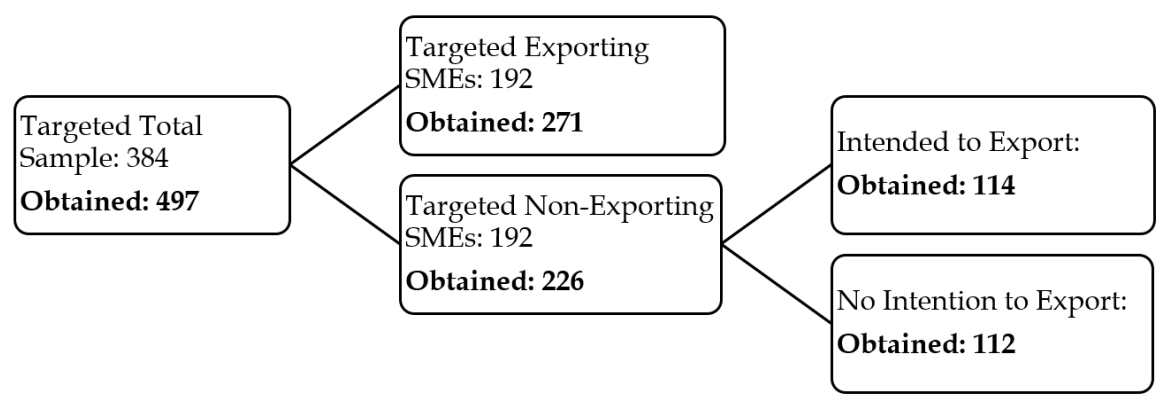

Figure 1: Sample Quota of SMEs and Realization

Table 2 illustrates the sample distribution by province and export status.

(Anderson et al., 2010; Crossley, 2008; Lee et al., 1999), and given as:

$$
\mathbf{n}=\left(\frac{\left(\mathbf{Z}_{\propto / 2}\right) \sigma}{\mathbf{M O E}}\right)^{2}
$$

where $n$ is the sample size; $\mathbf{Z}_{\propto / 2}$ is the value of the two-sided confidence interval in normal distribution, $\sigma$ represents the variation of the variable of interest and $M O E$ is the desired margin of error (Anderson et al., 2010; Crossley, 2008). Assuming that $\mathbf{Z}_{\propto / 2}=1.96$ (corresponds to a 95 percent confidence interval), response distribution $\sigma=0.5, M O E=0.05$, and $N=407,049$ (total number SMEs in Java, Madura, and Bali). 
A large number of answers have been gathered from East Java Province (185 SMEs, including Madura Island) and DKI Jakarta Province (100 SMEs). The two provinces are highly populated and industrialized. The following 212 participants were allocated to the following five regions (Banten, West Java, Central Java, DI Yogyakarta, and Bali).

Table 2: Sample Distribution of SMEs by Province and Export Status

\begin{tabular}{lcc|cc|cc}
\hline \multirow{2}{*}{ Province } & \multicolumn{2}{c}{ Exporter } & \multicolumn{2}{c}{ Non-Exporter } & \multicolumn{2}{c}{ Total by Province } \\
\cline { 2 - 7 } & Count & $\%$ & Count & $\%$ & Count & $\%$ \\
\hline Banten & 11 & 4.1 & 4 & 1.8 & 15 & 3.0 \\
DKI Jakarta & 56 & 20.7 & 44 & 19.5 & 100 & 20.1 \\
West Java & 19 & 7.0 & 20 & 8.8 & 39 & 7.8 \\
Central Java & 13 & 4.8 & 28 & 12.4 & 41 & 8.2 \\
DI Yogyakarta & 53 & 19.6 & 6 & 2.7 & 59 & 11.9 \\
East Java & 76 & 28.0 & 109 & 48.2 & 185 & 37.2 \\
Bali & 43 & 15.9 & 15 & 6.6 & 58 & 11.7 \\
\hline Total by Export Status & 271 & 100 & 226 & 100 & 497 & 100 \\
\hline Source: Author's calculation based on survey data & & &
\end{tabular}

Table 3 displays the allocation of respondents SMEs by commodities and export status. Seventy-four SMEs produce more than one type of product (multi products) while the remaining 423 SMEs specialize in a specific type of product, with the largest number in handicrafts (91 SMEs) and the lowest number in machinery components (18 SMEs).

Table 3: Sample Distribution of SMEs by Product and Export Status

\begin{tabular}{lcc|cc|cc}
\hline \multirow{2}{*}{ Products } & \multicolumn{2}{c}{ Exporter } & \multicolumn{2}{c}{ Non-Exporter } & \multicolumn{2}{c}{ Total by Products } \\
\cline { 2 - 7 } & Count & $\%$ & Count & $\%$ & Count & $\%$ \\
\hline Agricultural Products & 23 & 8.5 & 8 & 3.5 & 31 & 6.2 \\
Food and Beverages & 17 & 6.3 & 39 & 17.3 & 56 & 11.3 \\
Furniture & 43 & 15.9 & 37 & 16.4 & 80 & 16.1 \\
Handicrafts & 59 & 21.8 & 32 & 14.2 & 91 & 18.3 \\
Garments & 33 & 12.2 & 36 & 15.9 & 69 & 13.9 \\
Leather Products and Fashion Accessories & 15 & 5.5 & 17 & 7.5 & 32 & 6.4 \\
Household Utensils & 15 & 5.5 & 12 & 5.3 & 27 & 5.4 \\
Machinery Components & 7 & 2.6 & 11 & 4.9 & 18 & 3.6 \\
Other Products & 9 & 3.3 & 10 & 4.4 & 19 & 3.8 \\
Multi Products & 50 & 18.5 & 24 & 10.6 & 74 & 14.9 \\
\hline Total by Export Status & 271 & 100 & 226 & 100 & 497 & 100 \\
\hline
\end{tabular}

Source: Author's calculation based on survey data

In addition to the SME survey, this study also gathered information from nine central government agencies whose policy areas are directly or indirectly related to the development of SMEs or international trade activities. The survey of government agencies was aimed at capturing the perspectives of policy makers on export barriers faced by SMEs and identifying the provision of policy measures, programs and assistance related to the development or export development of SMEs. Table 4 shows the list of central government agencies and 
Table 4: Surveyed Central Government Agencies

\begin{tabular}{|c|c|}
\hline Ministries/Agencies & Functions Related to SMEs' Export Activities \\
\hline Ministry of Cooperatives and SMEs & $\begin{array}{l}\text { - Deputy for Production } \\
\text { - Deputy for Marketing and Business Networking } \\
\text { - Deputy for Human Resource Development } \\
\text { - Deputy for Financing }\end{array}$ \\
\hline Ministry of Industry & $\begin{array}{l}\text { - Directorate and Small and Medium Industries } \\
\text { - Directorate General of International Industry Cooperation }\end{array}$ \\
\hline Ministry of Trade & $\begin{array}{l}\text { - Directorate General of Foreign Trade } \\
\text { - National Agency for Export Development }\end{array}$ \\
\hline $\begin{array}{l}\text { National Agency for Development } \\
\text { Planning }\end{array}$ & $\begin{array}{l}\text { - Poverty, Employment and SMEs Section } \\
\text { - Economy Section }\end{array}$ \\
\hline Ministry of Foreign Affairs & $\begin{array}{l}\text { - Assistant Minister for Economic, Social and Cultural Af- } \\
\text { fairs }\end{array}$ \\
\hline Coordinating Ministry of Economy & $\begin{array}{l}\text { - Deputy for Coordinating International Economic Cooper- } \\
\text { ation } \\
\text { - Deputy for Coordinating Creative Economy, Entrepreneur- } \\
\text { ship and SMEs }\end{array}$ \\
\hline $\begin{array}{l}\text { Ministry of Maritime and Fishery } \\
\text { Affairs } \\
\text { Ministry of Tourism and Creative } \\
\text { Economy }\end{array}$ & $\begin{array}{l}\text { - Directorate General of Maritime and Fishery Product Com- } \\
\text { petitiveness } \\
\text { - Directorate General of Design, Technology and Media- } \\
\text { Based Creative Economy }\end{array}$ \\
\hline Ministry of Agriculture & $\begin{array}{l}\text { - Directorate General of Agriculture Product Processing and } \\
\text { Marketing }\end{array}$ \\
\hline
\end{tabular}

directorates-generals, deputies or functions within agencies that are relevant to the export activities of SMEs. In total, in various agencies, 36 survey responses were collected from officials.

Two collections of structured questionnaires with close-ended questions have been developed and translated into Bahasa Indonesia. The first batch of questionnaires was intended for small and medium-sized enterprises and the second set for central government institutions/agencies. The SME questionnaire was conducted randomly to 25 SMEs in the DKI Jakarta area before the SME survey was administered. The response to the SME survey questions required a good knowledge of the operational activities of the firms and therefore the questionnaires were administered to the owners or managers of SMEs.

\subsection{Export Barriers Analysis}

From the literature on export barriers discussed earlier, fifty specific types/items of export barriers were developed. Appendix 1 offers full details for each object. In the survey, all participants were questioned to show how serious/difficult each export barrier product was in a three-point Likert scale in the export operations of SMEs. ${ }^{12}$

\footnotetext{
${ }^{12}$ For the use of such scale in the survey of export barrier, see OECD (2012).
} 
The analysis of the Likert-scale response of the export barrier items is as follows. First, we rank the fifty export barrier items by their average Likert response scores to identify the major impediments to exports by SMEs. A strong median Likert score of an export barrier product refers to a elevated rate of complexity or seriousness of this sort of obstacle for SMEs (Hashim \& Ahmad, 2008; Liargovas \& Skandalis, 2008).

We also rank the export barrier items based on the average Likert response score given by government agencies. The ranks may represent policy makers' perceptions of the level of difficulties/severities of each export barrier and may reflect government agencies' priorities in assistance provision. Government agencies are likely to provide more assistance to remove the export barriers that they perceive as the most severe for SMEs, but less assistance for the barriers that they perceive as less difficult.

We plot government agencies' perceptions of the export barriers against SMEs' perceptions (obtained from SME survey) using a 3 × 3 grid (OECD-APEC, 2006). Figure 2 plots SMEs' perceived difficulties of export barrier items on the horizontal axis and the government agencies' perceived difficulties of export barrier items on the vertical axis. The fifty export barrier items are classified into three broad level of difficulties including the Top 25 percent (12 most difficult export barrier items).

For some export barrier items, government agencies may give higher average Likert response scores than SMEs (barrier items in Cells A, B, and D). The government agencies tend to over-provide the assistance to remove these types of barriers and therefore may reconsider the current level of assistance provisions. For the export barrier items placed in Cells H, I, and F, the government agencies give lower average Likert response scores than SMEs. The government agencies tend to underprovide the assistance to remove this type of barriers and therefore should look to increase the current level of provision. For export barrier items in Cells G, E, and C, both government agencies and SMEs give equally low, medium and high average Likert response scores, respectively. It is likely that the current level of assistance provision already meets SMEs' needs and therefore should be sustained (i.e. sustain low provision for barriers in Cell G, medium provision for barriers in Cell E and large provision for barriers in Cell C).

We also investigate the participation of SMEs in the export assistance provided by government agencies. In the SME study, participants were questioned if they received five kinds of help from any key public organizations including global trade fairs, publishing of SME catalogs, managerial training, technical training, and export financing, insurance and grants. The participants were also questioned if they received five forms of assistance from any local public agency, including technical training, managerial training, grants of equipment, grants of capital and international trade fairs. The independence test (Chi-square test) is used to examine the association between SMEs' export status (exporting and nonexporting) with their participation in export assistance provided by central and local government agencies. In addition, for every assistance that SMEs received 


\begin{tabular}{|c|c|c|c|c|}
\hline \multirow{3}{*}{$\begin{array}{l}\text { Government } \\
\text { agencies' } \\
\text { perspectives }\end{array}$} & $\begin{array}{l}\text { Very Difficult } \\
\text { (Top 25\%) }\end{array}$ & (A)Reconsider & (B) Reconsider: & (C) Sustain: \\
\hline & $\begin{array}{l}\text { Moderately difficult } \\
\quad \text { (Mid 50\%) }\end{array}$ & $\begin{array}{l}\text { (D) } \\
\text { Reconsider: }\end{array}$ & (E) Sustain: & (F) Increase: \\
\hline & $\begin{array}{l}\text { Less Difficult } \\
\text { (Bottom 25\%) }\end{array}$ & (G) Sustain: & (H) Increase: & (I) Increase: \\
\hline \multirow{2}{*}{\multicolumn{2}{|c|}{$\begin{array}{c}\text { Export Barriers' Rank based on } \\
\text { Likert Score }\end{array}$}} & $\begin{array}{l}\text { Less Difficult } \\
\text { (Bottom 25\%) }\end{array}$ & $\begin{array}{l}\text { Moderately } \\
\text { Difficult } \\
\text { (Mid 50\%) }\end{array}$ & $\begin{array}{l}\text { Very Difficult } \\
\text { (Top 25\%) }\end{array}$ \\
\hline & & \multicolumn{3}{|c|}{ SMEs' Perspectives } \\
\hline
\end{tabular}

Figure 2: Policy Options to Overcome Export Barriers Faced by SMEs Source: OECD-APEC (2006) and Lloyd-Reason and Mughan (2008)

from central or local government agencies, the respondents were asked to indicate the helpfulness of the assistance in a three-point Likert-scale ( $1=$ not helpful, $2=$ helpful, 3 = very helpful).

\section{Result}

\subsection{Export Assistance Provision by Central Government Agen- cies}

The surveyed SMEs were asked to indicate their participation in various types of export assistance from the central government. Table 5 summarizes the involvement of SMEs in five distinct programs of import support from key public organizations. Overall, exporting SMEs receive more assistance (total of 264 counts) than non-exporting SMEs (total of 116 counts). The most accessible export assistance is international trade fairs (e.g. international shows, exhibitions and exhibitions) followed by technical training (including specific production processes, packaging, logistics or machinery for specific markets) and managerial training (e.g. business planning, marketing, awareness of cultural differences, On the other hand, financial support (including export financing, export insurance and export guarantees) and SME Catalogue publications are the least accessed programs. However, the Chi-square test (insignificant at 5 percent level) indicates that there is no significant association between the export status of SMEs (exporting and non-exporting) and the types of central government export assistance that they access.

Next, we investigated whether SMEs at the pre-export stage (non-exporters) and those at the export stage (exporters) have the same needs for these five types of export assistance programs. Table 6 summarizes the perceived helpfulness of each export assistance program by SMEs (measured in a 3-point Likert scale where $1=$ not helpful, 2 = helpful, and $3=$ very helpful). Non-exporting SMEs 
Table 5: SMEs' Participation in Central Government Export Assistance Programs

\begin{tabular}{|c|c|c|c|c|c|c|c|}
\hline \multirow{2}{*}{$\begin{array}{l}\text { Export Assistance } \\
\text { Programs }\end{array}$} & \multicolumn{2}{|c|}{ Exporters } & \multicolumn{2}{|c|}{ Non-Exporters } & \multicolumn{2}{|c|}{ All Respondents } & \multirow{2}{*}{$\begin{array}{c}\text { Statistical } \\
\text { Test }\end{array}$} \\
\hline & Count & $\%$ & Count & $\%$ & Count & $\%$ & \\
\hline $\begin{array}{l}\text { International trade } \\
\text { fairs }\end{array}$ & 121 & 45.83 & 48 & 41.38 & 169 & 44.47 & $\chi^{2}=6.088$ \\
\hline $\begin{array}{l}\text { Publication of SME } \\
\text { Catalogue }\end{array}$ & 33 & 12.50 & 11 & 9.48 & 44 & 11.58 & \\
\hline Managerial training & 58 & 21.97 & 25 & 21.55 & 83 & 21.84 & \\
\hline Technical training & 40 & 15.15 & 29 & 25.00 & 69 & 18.16 & \\
\hline $\begin{array}{l}\text { Export financing, } \\
\text { insurance and } \\
\text { guarantee }\end{array}$ & 12 & 4.55 & 3 & 2.59 & 15 & 3.95 & \\
\hline Total & 264 & 100.00 & 116 & 100.00 & 380 & 100.00 & \\
\hline
\end{tabular}

Source: Author's calculation based on survey data

recorded financial export support as the most useful aid, accompanied by international trade fairs. In contrast, exporting SMEs perceived SME Catalogue as the most beneficial program followed by international trade fairs. This indicates that the most required export assistance for exporters (exporting phase) differs from those required by non-exporting SMEs (pre-export phase).

Furthermore, the mean difference test results suggest that exporting and nonexporting SMEs differ significantly in their perceived helpfulness in two export assistance programs: international trade fairs and export financial support (see last column in Table 6). These two kinds of export aid programs are considered to be more useful by non-exporting SMEs than by exporting SMEs. One possible explanation is that these types of export assistance are more effective in helping SMEs initiate/try exporting (early export stage) but less useful in sustaining or expanding exports (advanced export stage) (OECD-APEC, 2006).

Table 6: Helpfulness of Central Government Export Assistance Programs

\begin{tabular}{|c|c|c|c|c|c|}
\hline \multirow[b]{2}{*}{$\begin{array}{l}\text { Export Assistance } \\
\text { Programs }\end{array}$} & \multicolumn{3}{|c|}{ Mean Helpfulness Score } & \multicolumn{2}{|c|}{ Statistical Test } \\
\hline & Exporter & $\begin{array}{c}\text { Non } \\
\text { Exporter }\end{array}$ & $\begin{array}{c}\text { All } \\
\text { Respondents }\end{array}$ & $\begin{array}{l}\text { Equality of } \\
\text { Variances }\end{array}$ & $\begin{array}{c}\text { Mean } \\
\text { Difference }\end{array}$ \\
\hline International trade fairs & 2.57 & 2.77 & 2.63 & $14.997^{* * *}$ & $-2.538^{* *}$ \\
\hline $\begin{array}{l}\text { Publication of SME } \\
\text { Catalogue }\end{array}$ & 2.64 & 2.45 & 2.59 & 0.086 & 0.837 \\
\hline Managerial training & 2.54 & 2.6 & 2.56 & 1.032 & -0.460 \\
\hline Technical training & 2.43 & 2.62 & 2.51 & 0.583 & -1.612 \\
\hline $\begin{array}{l}\text { Export financing, } \\
\text { insurance and } \\
\text { guarantee }\end{array}$ & 2.42 & 3.00 & 2.53 & $12.740^{* * *}$ & $-3.023^{* *}$ \\
\hline
\end{tabular}

Source: Author's calculation based on survey data

Note: Equality of variances assumption is checked with Levene's test

$\left.{ }^{* *}\right)$ and $\left({ }^{* *}\right)$ represent 5 percent and 1 percent significant levels, respectively 


\subsection{Export Assistance Provision by Local Government Agencies}

The SMEs surveyed were asked to indicate their involvement in various types of export assistance provided by local government agencies (provincial, municipal, and regency government agencies). Table 7 summarizes the participation of SMEs in export assistance programs of five different provincial government agencies. Overall, exporting SMEs receive more assistance (total of 238 counts) than nonexporting SMEs (total of 138 counts). Exporting SMEs participate more actively in all export assistance programs, except for capital grants.

Table 7: SMEs' Participation in Provincial Government Export Assistance Programs

\begin{tabular}{lcc|cc|ccc}
\hline \multirow{2}{*}{$\begin{array}{l}\text { Export Assistance } \\
\text { Programs }\end{array}$} & \multicolumn{2}{c}{ Exporters } & \multicolumn{2}{c}{ Non-Exporters } & \multicolumn{2}{c}{ All Respondents } & Statistical \\
\cline { 2 - 7 } & Count & $\%$ & Count & $\%$ & Count & $\%$ & Test \\
\hline Technical training & 66 & 27.73 & 30 & 21.74 & 96 & 25.53 & $\chi^{2}=9.946^{* *}$ \\
Managerial training & 66 & 27.73 & 37 & 26.81 & 103 & 27.39 & \\
Grants of equipment & 23 & 9.66 & 20 & 14.49 & 43 & 11.44 & \\
Grants of capital & 21 & 8.82 & 24 & 17.39 & 45 & 11.97 & \\
International trade & 62 & 26.05 & 27 & 19.57 & 89 & 23.67 & \\
$\quad$ fairs & 238 & 100.00 & 138 & 100.00 & 376 & 100.00 & \\
\hline Total & & & & & & & \\
\hline
\end{tabular}

Source: Author's calculation based on survey data

Note: ${ }^{* *}$ ) represents 5 percent significance level

Moreover, the Chi-square test (significant at 5 percent level) indicates that there is a significant relationship between the export status of SMEs (exporting and non-exporting) and the types of export assistance they access. The participation of exporters is highly concentrated in three programs-technical training, managerial training, and international trade fairs (81.51 percent of total participation). On the contrary, the participations of non-exporting SMEs varied across five export assistance programs of the provincial government.

Table 8 summarizes the involvement of SMEs interviewed in export aid programs of municipal/regency public organizations. Overall, the most accessed municipal government programs are technical and managerial training, respectively. However, the insignificant Chi-square test indicates that there is no relationship between the export status of SMEs (exporting and non-exporting) and the types of export assistance that SMEs participate in.

Next we investigate the helpfulness of the export assistance of local government agencies (at both provincial and municipal levels) for export activities of SMEs. Table 9 summarizes the perceived helpfulness of each export assistance program. Overall, exporting SMEs receive more assistance (total of 121 counts) than non-exporting SMEs (total of 104 counts). Both exporting and non-exporting SMEs viewed international trade fairs and capital grants as the first and second most useful help, respectively. The mean difference test results, however, suggest that exporting and non-exporting SMEs differ significantly in the perceived helpfulness of one type of assistance-managerial training. Interestingly, managerial training is perceived as being more beneficial by non-exporting SMEs than by 
Table 8: SMEs' Participation in Municipal Government Export Assistance Programs

\begin{tabular}{lcc|cc|ccc}
\hline Export Assistance & \multicolumn{2}{c}{ Exporters } & \multicolumn{2}{c}{ Non-Exporters } & \multicolumn{2}{c}{ All Respondents } & Statistical \\
\cline { 2 - 7 } Programs & Count & $\%$ & Count & $\%$ & Count & $\%$ & Test \\
\hline Technical training & 38 & 31.40 & 41 & 39.42 & 79 & 35.11 & $\chi^{2}=6.559$ \\
Managerial training & 39 & 32.23 & 20 & 19.23 & 59 & 26.22 & \\
Grants of equipment & 11 & 9.09 & 13 & 12.50 & 24 & 10.67 & \\
Grants of capital & 21 & 17.36 & 23 & 22.12 & 44 & 19.56 & \\
International trade & 12 & 9.92 & 7 & 6.73 & 19 & 8.44 & \\
$\quad$ fairs & & & & & & & \\
\hline Total & 121 & 100.00 & 104 & 100.00 & 225 & 100.00 & \\
\hline
\end{tabular}

Source: Author's calculation based on survey data

Table 9: Helpfulness of Regional Government Programs

\begin{tabular}{lccc|cc}
\hline Export Assistance & \multicolumn{3}{c}{ Mean Helpfulness Score } & \multicolumn{2}{c}{ Statistical Test } \\
\cline { 2 - 6 } Programs & Exporter & $\begin{array}{c}\text { Non } \\
\text { Exporter }\end{array}$ & $\begin{array}{c}\text { All } \\
\text { Respondents }\end{array}$ & $\begin{array}{c}\text { Equality of } \\
\text { Variances }\end{array}$ & $\begin{array}{c}\text { Mean } \\
\text { Difference }\end{array}$ \\
\hline Technical training & 2.28 & 2.40 & 2.33 & $4.301^{* *}$ & -1.217 \\
Managerial training & 2.22 & 2.40 & 2.29 & $3.062^{*}$ & $-1.715^{*}$ \\
Grant of equipment & 2.24 & 2.42 & 2.32 & 0.241 & -0.985 \\
Grant of capital & 2.40 & 2.59 & 2.50 & 1.142 & -1.307 \\
International trade & 2.59 & 2.64 & 2.60 & 0.000 & -0.442 \\
$\quad$ fairs & & & & & \\
\hline
\end{tabular}

Source: Author's calculation based on survey data

Note: Equality of variance assumption is checked with Levene's test

$\left(^{*}\right)$ and $\left({ }^{* *}\right)$ represent 10 percent and 5 percent significance levels, respectively

exporting SMEs. The probable reason is that such export aid could be more efficient in assisting SMEs initiate/attempt to export but less helpful in maintaining or extending it (OECD-APEC, 2006).

\subsection{Mismatch in the Perceived Difficulty of Export Barriers}

While the above sections explain the prevailing assistance for export, this section provides the discussion on the barriers for export. Specifically, this section provides the main perceived export barriers by the SMEs juxtaposed with such by the government, including the differences they possess. Hence, the mismatch of the perceived export barriers by the SMEs and the policymakers can be identified.

Table 10 shows the ten most difficult export barriers faced by the surveyed SMEs based on average Likert response scores. Appendix 2 provides the full lists of the 50 export barrier responses. Overall, foreign currency exchange risks are the most severe barrier to export. The literature indicates at least three methods in which the exchange rate may adversely influence SMEs. First, overseas market demand for products from SMEs may fluctuate with the exchange rate (Geng \& Geng, 2012). Second, sometimes the contract with foreign buyers fixes the price of the product in terms of foreign currency value, so the fluctuation of the exchange rate can affect the actual domestic currency revenue of SMEs (Helísek, 2013). Third, SMEs' production often requires imported raw materials, whose prices 
may fluctuate with exchange rates and in turn affect SMEs' costs of production.

Further, the next four main export barriers perceived were: B9 (Shortage of export insurance); B10 (Granting credit facilities or payment delay to foreign customers); B36 (Economic fluctuations in target markets); and B32 (Unequal treatment in business competition law in target markets). We note that generally, the main export barriers perceived by the SMEs that were deemed most pressing are more related to the distribution and financing aspect, while the rest (rank 4 to 10) are more related to the target markets' characteristics.

Table 10: Ten Main Export Barriers Perceived by SMEs

\begin{tabular}{|c|c|c|c|c|c|}
\hline \multirow{2}{*}{ Rank } & & \multirow{2}{*}{ Export Barriers } & \multirow{2}{*}{$\mathrm{N}$} & \multicolumn{2}{|c|}{ Likert Score } \\
\hline & & & & Mean & Std. Dev. \\
\hline 1 & B37 & High risks of foreign exchange & 496 & 2.35 & 0.672 \\
\hline 2 & B9 & Shortage of export insurance & 496 & 2.33 & 0.689 \\
\hline 3 & B10 & $\begin{array}{l}\text { Granting credit facilities or payment delay to } \\
\text { foreign customers }\end{array}$ & 497 & 2.30 & 0.688 \\
\hline 4 & B36 & Economic fluctuations in target markets & 496 & 2.30 & 0.628 \\
\hline 5 & B32 & $\begin{array}{l}\text { Unequal treatment in business competition law } \\
\text { in target markets }\end{array}$ & 496 & 2.29 & 0.620 \\
\hline 6 & B26 & $\begin{array}{l}\text { Enforcing contracts/resolving disputes in target } \\
\text { markets }\end{array}$ & 495 & 2.22 & 0.639 \\
\hline 7 & B21 & $\begin{array}{l}\text { Offering technical/after-sales service in target } \\
\text { markets }\end{array}$ & 493 & 2.20 & 0.675 \\
\hline 8 & B29 & Restriction of asset ownership in target markets & 496 & 2.20 & 0.617 \\
\hline 9 & B33 & Sophisticated target markets' laws/ regulations & 494 & 2.20 & 0.624 \\
\hline 10 & B45 & $\begin{array}{l}\text { (Intellectual) property rights protection in target } \\
\text { markets }\end{array}$ & 495 & 2.19 & 0.650 \\
\hline
\end{tabular}

Source: Author's calculation based on survey data

Note: The Likert-scale ranges from 1 = not difficult, 2 = difficult and 3 = very difficult

Further, we discuss the main export barriers perceived by the policymakers. We note that, policymakers generally agree that the main export barrier would be the restriction of asset ownership in target markets (B29). The next four export barriers are: B46 (Health, safety, and technical standards in target markets); B30 (Unequal treatment in tax/eligibility to affiliate in target markets); B08 (Shortage of investment capital), and B32 (Unequal treatment in business competition law in target markets).

Arguably, the policymakers deem the barriers more related to the target market's characteristics and/or competition landscape as the more pressing issue. Table 11 shows the ten most difficult export barriers faced by small and medium-sized enterprises based on average Likert response scores, perceived by policymakers.

We note that while there are several similarities of main export barriers perceived by SMEs as practitioners and the policymakers as regulators (e.g., both deem intellectual property rights, unequal treatment in business competition in target market, among others as similarly important), a general difference in perspective is rather stark. As we explored above, we notice that the policymakers generally perceive difficulties and characteristics in the target markets to be the 
Table 11: Ten Main Export Barriers Perceived by Policy Makers

\begin{tabular}{|c|c|c|c|c|c|}
\hline \multirow{2}{*}{ Rank } & & \multirow{2}{*}{ Export Barriers } & \multirow{2}{*}{$\mathrm{N}$} & \multicolumn{2}{|c|}{ Likert Score } \\
\hline & & & & Mean & Std. Dev. \\
\hline 1 & B29 & Restriction of asset ownership in target markets & 36 & 2.500 & 0.5606 \\
\hline 2 & B46 & $\begin{array}{l}\text { Health, safety and technical standards in target } \\
\text { markets }\end{array}$ & 36 & 2.444 & 0.5578 \\
\hline 3 & $\mathrm{~B} 30$ & $\begin{array}{l}\text { Unequal treatment in tax/eligibility to affiliate in } \\
\text { target markets }\end{array}$ & 36 & 2.417 & 0.6036 \\
\hline 4 & B08 & Shortage of investment capital & 36 & 2.389 & 0.6449 \\
\hline 5 & B32 & $\begin{array}{l}\text { Unequal treatment in business competition law in } \\
\text { target markets }\end{array}$ & 36 & 2.361 & 0.6393 \\
\hline 6 & B21 & $\begin{array}{l}\text { Offering technical/after-sales service in target } \\
\text { markets }\end{array}$ & 36 & 2.333 & 0.5345 \\
\hline 7 & B48 & $\begin{array}{l}\text { Quotas and/or embargoes imposed by target } \\
\text { markets }\end{array}$ & 36 & 2.333 & 0.5345 \\
\hline 8 & B50 & Preferential tariff for exporters from other countries & 36 & 2.333 & 0.5855 \\
\hline 9 & B37 & High risks of foreign currency & 36 & 2.306 & 0.5248 \\
\hline 10 & B33 & Sophisticated target markets' laws/regulations & 36 & 2.278 & 0.6595 \\
\hline 11 & B45 & $\begin{array}{l}\text { (Intellectual) property rights protection in target } \\
\text { markets }\end{array}$ & 36 & 2.278 & 0.5133 \\
\hline
\end{tabular}

Source: Author's calculation based on survey data

Note: The Likert-scale ranges from 1 = not difficult, 2 = difficult and 3 = very difficult

more pressing issue (e.g., asset ownership, health and technical standards, tax treatments in target market, among others). Meanwhile the SMEs, while also acknowledging that such barriers are important, are instead more concerned with rather the financing and export-enabling aspects, such as exchange rate, insurance, and credit facilities.

The difference, we argue, points out the lack of perspectives alignment between the SMEs and the policymakers. To put simply, the policymakers are concerned on how the Indonesian export products will compete in the target markets while, ironically, the products may not reach the destined market due to existing financing barriers, for instance. This calls for the policymakers not to only assume that barriers generally appear once the goods arrive at the target markets in terms of competitiveness issues, but instead also on enabling the exporting firms to fundamentally be exporting. Such mismatch might prove to be a hindrance towards the prevailing exporting activities, calling for the right policies to be made. We discuss the relevant policy options, taking into account such differing perceptions between SMEs and policymakers in the next section.

\subsection{Policy Options to Remove Export Barriers}

The survey to policymakers was administered to government agencies whose policy areas are related to the exporting activities of SMEs. The survey asked each agency's key person(s) to indicate their perception of the difficulties of different types of export barriers faced by SMEs. The survey used 50 export barrier items and a 3-point Likert scale measure similar to those used in the survey for SMEs. 
Appendix 2 provides the full outcomes of the average Likert reaction rating of the 50 export barrier products given by government agencies.

Government agencies develop and provide export assistance based on various factors, one of which is their own perception of export barriers faced by SMEs. Government agencies will provide more assistance to remove the barriers they perceive as very difficult barriers, but medium and low provision of aid to remove the barriers they perceive as moderately difficult and less difficult, respectively. We are therefore examining whether the views of government agencies are compatible with the views of SMEs on export barriers. Figure 3 shows the perceptions of policymakers of export obstacles on the vertical axis against the expectations of SMEs (earlier mentioned in Section 3.2) on the horizontal axis.

Figure 3 is interpreted as follows. Cell G includes all the barriers that SMEs and government agencies perceive as less difficult. It is therefore possible to retain the current minimum government attention to remove B1, B12, B14, B2, B24, B39, $\mathrm{B} 40$, and B41. Cell E involves all the obstacles that SMEs and government agencies regard as mildly challenging. It is therefore possible to retain the current medium level of government assistance to remove B16, B17, B19, B20, B22, B25, B3, B38, B42, B47, B49, B5, B6, and B7. Analogously, Cell C involves all the obstacles that SMEs and government agencies regard as very hard. The current government must therefore pay maximum attention to remove B21, B26, B29, B30, B32, B33, B37, and B45 should be retained.

\begin{tabular}{|cc|l|l|l|}
\hline & $\begin{array}{c}\text { Very } \\
\text { Difficult } \\
(\text { Top 25\%) }\end{array}$ & (B) Reconsider & (B) Reconsider: \\
B44, B46, B48, B50, B8 & $\begin{array}{l}\text { (C) Sustain: } \\
\text { B21, B26, B29, } \\
\text { B30, B32, B33, } \\
\text { B37, B45 }\end{array}$ \\
\cline { 2 - 6 } $\begin{array}{c}\text { Government } \\
\text { agencies' } \\
\text { perspectives }\end{array}$ & $\begin{array}{c}\text { Moderately } \\
\text { difficult } \\
\text { (Mid 50\%) }\end{array}$ & $\begin{array}{l}\text { (D) } \\
\text { Reconsider: } \\
\text { B11, B13, B34, } \\
\text { B4, B43 }\end{array}$ & $\begin{array}{l}\text { (E) Sustain: } \\
\text { B16, B17, B19, B20, } \\
\text { B22, B25, B3, B38, B42, } \\
\text { B47, B49, B5, B6, B7 }\end{array}$ & $\begin{array}{l}\text { (F) Increase: } \\
\text { B10, B18, B35, }\end{array}$ \\
\cline { 2 - 6 } & $\begin{array}{c}\text { Less } \\
\text { Difficult } \\
\text { (Bottom } \\
25 \%)\end{array}$ & $\begin{array}{l}\text { (G) Sustain: } \\
\text { B1, B12, B14, } \\
\text { B2, B24, B39, } \\
\text { B40, B41 }\end{array}$ & $\begin{array}{l}\text { (H) Increase: } \\
\text { B15, B23, B27, B28, } \\
\text { B31 }\end{array}$ & (I) Increase \\
\hline $\begin{array}{c}\text { Export Barriers' Rank } \\
\text { based on Likert Score }\end{array}$ & $\begin{array}{l}\text { Less Difficult } \\
\text { (Bottom 25\%) }\end{array}$ & $\begin{array}{c}\text { Moderately Difficult } \\
\text { (Mid 50\%) } \\
\text { SMEs' Perspectives }\end{array}$ & $\begin{array}{c}\text { Very Difficult } \\
\text { (Top 25\%) }\end{array}$ \\
\hline
\end{tabular}

Figure 3: Policy Options to Overcome Export Barriers Faced by SMEs Source: Author's calculation based on survey data

Cells F, H, and I include all the export obstacles that government agencies consider not to be as hard as SMEs find them. Therefore, the current level of assistance provided by the government to remove B10, B18, B35, B36, B9, B15, B23, B27, B28, and B31 is probably lower than the SMEs actually need. The government may therefore increase the provision of assistance to remove these 
barriers.

Cells A, B, and D include all the export obstacles that government agencies consider to be harder than SMEs think. Therefore, the current levels of assistance provided by the government to remove B44, B46, B48, B50, B8, B11, B13, B34, B4, and $\mathrm{B} 43$ are possibly higher than SMEs actually need. Thus, the government can reconsider (reduce) the assistance to remove those barriers.

\section{Conclusion}

\subsection{Summary and Major Findings}

Indonesia faces rapid changes in its international trade policies and environment due to its engagement in various bilateral, regional and multilateral free trade agreements. On the one hand, free trade escalates business competition for SMEs in the domestic market through cheap imported products and the increasing operation of foreign enterprises. On the other hand, free trade also offers enormous opportunities for SMEs to export and to venture abroad.

However, SMEs are less able to take advantage of foreign market opportunities than larger enterprises, as indicated by the marginal contribution to Indonesia's exports. SMEs only account for a small share of Indonesia's non-oil and gas exports and the share tends to decline over time. This contradicts SMEs' increasingly important role in the Indonesian economy, particularly as they have been Indonesia's major source of business establishment, employment provision and value added creation.

This study investigates the internationalization of Indonesian SMEs, particularly their direct-exporting activities. In particular, this study identifies the main factors that act as the main export barriers. Further, this study investigates the mismatch of perceived barriers between SMEs and the policymakers. Accurate identification of export barriers is imperative in SME internationalization. The policy measures to foster SMEs' exports are formulated based on the research results.

The findings show that government agencies play an important role in facilitating SME internationalization. Exporting SMEs receive more assistance than non-exporting SMEs from the central government in all types of assistance including international trade fairs, publication of SME Catalogues, managerial training, technical training, and export financing, insurance and guarantees.

However, the empirical results indicate that the effectiveness of government assistance is probably crippled by government's misperceptions of the severity/difficulties of some types of export barriers faced by SMEs. For example, government agencies perceive that granting credit facilities or payment delay to foreign customers (B10), obtaining reliable foreign representation (B18), and stiff competition in target markets (B35) are not as difficult as SMEs perceive Hence, the government's current levels of assistance provision to remove those barriers are probably lower than the level that SMEs actually need. In contrast, 
government agencies perceive high tariff costs in target markets (B44), quotas and/or embargoes imposed by target markets (B48), and developing new products for foreign markets (B11) as more difficult than SMEs perceive. Hence, the government's current level of assistance provision to tackle those barriers is possibly higher than the level SMEs actually need.

Hence, the government should formulate export assistance programs based on accurate information on export barriers faced by SMEs. Accordingly, the government should have a good understanding of the severity and urgency of each type of export barriers, with which effective policy measures can be formulated. The results above revealed that misperceptions about the types and the difficulty level of export barriers may lead to under or over provision of export assistance in certain policy areas. This misperceptions of export barriers between policy makers and SMEs are not uncommon, even in developed countries (see for example Lloyd-Reason \& Mughan, 2008; OECD-APEC, 2006). To obtain accurate information on export barriers, government agencies should proactively gather feedbacks from SMEs and various actors in the internationalization networks. For example, government agencies can regularly perform SME surveys in cooperation with universities and research institutes.

Further, the central government must disseminate their policy supports for SMEs internationalization to provincial, municipal and regency governments and coordinate its policy implementation. Since Indonesia's government decentralization in 1999, the local governments have played increasingly important roles in the policymaking (Brodjonegoro \& Asanuma, 2000; Resosudarmo, 2004). Revindo (2017) reported that local government assistance has no significant effect in helping SMEs to become exporters or to sustain and expand their exporting. Without central government's direction, the local government may have stronger domestic market orientation in their assistance to local SMEs (Uchikawa \& Keola, 2009).

\subsection{Research Limitations and Future Studies}

This research has a number of limitations regarding the scope of the study, the sample selection, the data and the estimation techniques. This study restricts the analysis to SMEs' direct exporting activities, which is one specific form of outward internationalization. Therefore, this research does not integrate other forms of outward internationalization including indirect export through large exporting firms, involvement in global supply chains and foreign investment to set up shops or inventory facilities overseas. Direct exporting is an increasingly viable outward internationalization strategy for SMEs due to decreasing trade barriers and transportation costs but indirect export and involvement in global supply chains remain as realistic options for SMEs owing to their risk aversion and lack of internal resources (Hessels \& Terjesen, 2010).

This research focuses on the export barriers faced by small-sized and mediumsized enterprises and therefore excludes the case of micro-sized enterprises. The 
database of micro enterprises in Indonesia is inaccessible as they usually take the form of individual enterprises or home industries. Furthermore, micro enterprises are less likely to engage in direct exporting activities due to their smallness and limited resources (Pendergast et al., 2008), despite the decrease in trade barriers and the advancement of information and communication technology.

This research covers seven provinces in Indonesia including all provinces in Java, Madura and Bali Islands. Of the thirty-four total provinces in Indonesia, the seven studied provinces contribute approximately 58 percent of total GDP and 53 percent of total non-oil and gas exports, and are the centers of economic activities and growth in Indonesia (BPS-Statistics Indonesia, 2014c). Approximately 57.5 percent of the total population and 60 percent of total SMEs in Indonesia also live in the seven provinces. The selection of the study region therefore enables the generalization of the outcomes of the research at country level (Indonesia) to some extent. However, the study findings do not reflect the characteristics of provinces that vary significantly from the provinces studied. In particular, the results may not reflect the least industrialized and least developed provinces where the lack of transportation, communication and logistics infrastructure may pose greater barriers for exporting activities.

Finally, this study uses a cross-sectional approach to analyze the impact of exporting using perceptual firm performance improvement data measured with Likert-scale questions. Hence, the study did not conduct a comparison of firm performance before and after exporting with actual financial performance data, with which more advanced data analysis methods such as difference-in differences and panel data analysis can be employed.

The scope of the study can be extended to include other areas or provinces in Indonesia in order to improve the generalization of research outcomes. In specific, future research may try to include less developed/less industrialized provinces and regions with neighboring ASEAN countries close to the Indonesian boundaries. Provinces can also differ in their local governments' policies towards local SMEs. Accordingly, cross-province comparison of SME internationalization requires a larger sample size. The sample size should be calculated and randomized for each province to ensure sample sufficiency to perform statistical inferences at provincial level.

Alternatively, future research can be more specific on SME internationalization in a particular province/region or product group/industry. For example, case studies of SME internationalization in tourist destination provinces such as Bali and Yogyakarta can be considered. Case studies can also be drawn upon internationalization of SMEs in specific industries such as handicrafts, food and beverages, and garment and fashion accessories. Specific case studies will allow more specific policy measures recommendation to foster SME internationalization. 


\section{References}

[1] Adlung, R., \& Soprana, M. (2013). SMEs in services trade - A GATS perspective. Intereconomics, 48(1), 41-50. doi: https://doi.org/10.1007/s10272-013-0443-1.

[2] Anderson, D. R., Sweeney, D. J., \& Williams, T. A. (2010). Statistics for business and economics (11th edition.). South Western Educational Publishing.

[3] Awuah, G. B., \& Amal, M. (2011). Impact of globalization: the ability of less developed countries' (LDCs') firms to cope with opportunities and challenges. European Business Review, 23(1), 120-132. doi:10.1108/09555341111098026.

[4] Bilkey, W. J., \& Tesar, G. (1977). The export behavior of smaller-sized Wisconsin manufacturing firms. Journal of International Business Studies, 8(1), 93-98. doi: ttps://doi.org/10.1057/palgrave.jibs.8490783.

[5] BPS-Statistics Indonesia. (2014a). Industry Statistics. Jakarta: BPS-Statistics Indonesia.

[6] BPS-Statistics Indonesia. (2014b). Statistical Yearbook of Indonesia 2014. Jakarta: BPSStatistics Indonesia.

[7] BPS-Statistics Indonesia. (2014c). Value of Exports by Major Ports (FOB value: million US\$), 2000-2013. Retrieved from 5 October 2016 from https://www.bps.go.id/ linkTabelStatis/view/id/1008.

[8] Breinlich, H., \& Criscuolo, C. (2011). International trade in services: A portrait of importers and exporters. Journal of International Economics, 84(2), 188-206. doi: http://dx.doi.org/10.1016/j.jinteco.2011.03.006.

[9] Brodjonegoro, B., \& Asanuma, S. (2000). Regional autonomy and fiscal decentralization in democratic Indonesia. Hitotsubashi Journal of Economics, 41(2), 111-122.

[10] Calof, J. L., \& Beamish, P. W. (1995). Adapting to foreign markets: Explaining internationalization. International Business Review, 4(2), 115-131. doi: 10.1016/09695931(95)00001-G.

[11] Crossley, M. L. (2008). The desk reference of statistical quality methods. ASQ Quality Press.

[12] Dalli, D. (1995). The organization of exporting activities: Relationships between internal and external arrangements. Journal of Business Research, 34(2), 107-115. doi: http:/ /dx.doi.org/10.1016/0148-2963(94)00059-N.

[13] EFIC. (2010). Global readiness index: National summary report 2010. Export Finance and Insurance Corporation.

[14] Freeman, S., Edwards, R., \& Schroder, B. (2006). How smaller born-global firms use networks and alliances to overcome constraints to rapid internationalization. Journal of International Marketing, 14(3), 33-63. doi:10.2307/25049054.

[15] Geng, M., \& Geng, X. (2012). Two-factor export factoring: Optimal option for exportoriented SMEs financing. Contemporary Logistics, (6), 86-90.

[16] Hammer, A., \& Stamps, J. (2010). The role of small \& medium sized enterprises in U.S. and EU exports. Paris: OECD.

[17] Hashim, F. (2012). Challenges for the internationalization of SMEs and the role of government: The case of Malaysia. Journal of International Business and Economy, 13(1), 97-122.

[18] Hashim, M. K., \& Ahmad, S. (2008). Internationalization of Malaysian SME's influencing factors, sources of information and options. Paper presented at the meeting of the International Council for Small Business World Conference, Halifax, Nova Scotia, Canada.

[19] Helísek, M. (2013). Export potential of SMEs and Euro adoption in the Czech Repub- 
lic. European Research Studies Journal, 16(4), 71-78. EOI: 10.11214/thalassinos.16.04.006.

[20] Hessels, J., \& Terjesen, S. (2010). Resource dependency and institutional theory perspectives on direct and indirect export choices. Small Business Economics, 34(2), 203-220. doi: 10.1007/s11187-008-9156-4.

[21] Hollenstein, H. (2005). Determinants of international activities: are SMEs different? Small Business Economics, 24(5), 431-450. doi: https://doi.org/10.1007/s11187-0056455-x.

[22] Hymer, S. H. (1976). The international operations of national firms: A study of direct foreign investment. Cambridge, MA: MIT Press.

[23] Indonesia, R. (2008). Undang-undang No. 20 Tahun 2008 tentang Usaha Mikro Kecil dan Menengah [Law on Micro, Small and Medium-Sized Enterprise Number 20 of 2008].

[24] ITC. (2016a). Trade map: Export by products. International Trade Centre. Retrieved 16 August 2016 from http:/ / www.trademap.org/Index.aspx.

[25] ITC. (2016b). Trade map: Export by services. International Trade Centre. Retrieved 7 September 2016 from http:/ / www.trademap.org/Index.aspx.

[26] Jane, O. (2013). Proses internasionalisasi perusahaan: Desain strategis \& organisasi (studi kasus UKM di kota Bandung). Research Report - Humanities and Social Science, 1.

[27] Knight, G. (2000). Entrepreneurship and marketing strategy: The SME under globalization. Journal of International Marketing, 8(2), 12-32. doi: https://doi.org/10.1509\%2Fjimk.8.2.12.19620.

[28] Köcker, G. M., \& Buhl, C. M. (2007). Internationalization of Networks - Barriers and Enablers: Empirical analysis of selected European networks. Berlin: Kompetenznetze Deutschland, Federal Ministry of Economics and Technology Germany.

[29] Kogut, B., \& Chang, S. J. (1996). Platform Investments and Volatile Exchange Rates: Direct Investment in the U.S. by Japanese Electronics Companies. The Review of Economics and Statistics, 78(2), 221-231. doi:10.2307/2109924.

[30] Kuncoro, M. (2009). Pemberdayaan UKM: Antara mitos dan realitas. Jogjakarta: Pusat Studi Ekonomi Kerakyatan, Universitas Gajah Mada.

[31] Laghzaoui, S. (2007, October). Internationalization of SME: A reading in terms of resources and competencies. Paper presented at the meeting of the $3 \mathrm{rd}$ Iberian International Business Conference, Aveiro, Portugal.

[32] Lee, C. F., Lee, J. C., \& Lee, A. C. (1999). Statistics for business and financial economics (2nd edition). Singapore: World Scientific.

[33] Leonidou, L. C. (1995). Empirical research on export barriers: Review, assessment, and synthesis. Journal of International Marketing, 3(1), 29-43. doi: https://doi.org/10.1177\%2F1069031X9500300103.

[34] Leonidou, L. C. (2004). An analysis of the barriers hindering small business export development. Journal of Small Business Management, 42(3), 279-302. doi: 10.1111/j.1540627X.2004.00112.x.

[35] Liargovas, P. G., \& Skandalis, K. S. (2008). Motivations and barriers of export performance: Greek exports to the Balkans. Journal of Southern Europe and the Balkans Online, 10(3), 377-392. doi: 10.1080/14613190802493840.

[36] Lloyd-Reason, L., \& Mughan, T. (2008). Removing barriers to SME access to international markets: OECD-APEC global study. Paper presented at the meeting of the USASB 2008 Conference, San Antonio, Texas.

[37] Ministry of Cooperatives and SMEs Republic of Indonesia. (2009a). Direktori KUKM ekspor. Jakarta.

[38] Ministry of Cooperatives and SMEs Republic of Indonesia. (2009b). Perkem- 
bangan data Usaha Mikro, Kecil, Menengah (UMKM) dan Usaha Besar (UB) tahun 2005-2009 [The development of Micro, Small, Medium and LargeSized Business, 2005-2009]. Retrieved June 15, 2013 from http://www. depkop.go.id/index.php?option=com_phocadownload\&view=file\&id=318: data-usaha-mikro-kecil-menengah-umkm-dan-usaha-besar-ub-tahun-20102011\&Itemid $=93$.

[39] Ministry of Cooperatives and SMEs Republic of Indonesia. (2010a). Perkembangan data Usaha Mikro, Kecil, Menengah (UMKM) dan Usaha Besar (UB) tahun 2006-2010 [The development of Micro, Small, Medium and Large-Sized Business, 2006-2010]. Retrieved September 7, 2016 from http://www. depkop.go.id /index.php?option=com_phocadownload\&view=file\&id=318: data-usaha-mikro-kecil-menengah-umkm-dan-usaha-besar-ub-tahun-20102011\&Itemid $=93$.

[40] Ministry of Cooperatives and SMEs Republic of Indonesia. (2010b). Perkembangan data Usaha Mikro, Kecil, Menengah (UMKM) dan Usaha Besar (UB) tahun 2009-2010 [The development of Micro, Small, Medium and Large-Sized Business, 2009-2010]. Retrieved September 7, 2016 from http://www. depkop.go.id/index.php?option=com_phocadownload\&view=file\&id=318: data-usaha-mikro-kecil-menengah-umkm-dan-usaha-besar-ub-tahun-20102011\&Itemid $=93$.

[41] Ministry of Cooperatives and SMEs Republic of Indonesia. (2011). SME and Cooperative Indonesia catalogue. Jakarta.

[42] Ministry of Cooperatives and SMEs Republic of Indonesia. (2012). SME and Cooperative Indonesia catalogue. Jakarta.

[43] Ministry of Cooperatives and SMEs Republic of Indonesia. (2013). Perkembangan data Usaha Mikro, Kecil, Menengah (UMKM) dan Usaha Besar (UB) tahun 2010-2011 [The Development of Micro, Small, Medium and LargeSized Business, 2010-2011]. Retrieved June 15, 2013 from http://www. depkop.go.id/index.php?option=com_phocadownload\&view $=$ file\&id=318: data-usaha-mikro-kecil-menengah-umkm-dan-usaha-besar-ub-tahun-20102011\&Itemid $=93$.

[44] Ministry of Cooperatives and SMEs Republic of Indonesia. (2014a). Perkembangan data Usaha Mikro, Kecil, Menengah (UMKM) dan Usaha Besar (UB) Tahun 2011-2012 [The development of Micro, Small, Medium and Large-Sized Business, 2010-2012].

[45] Ministry of Cooperatives and SMEs Republic of Indonesia. (2014b). Statistik Usaha Mikro, Kecil dan Menengah (UMKM) tahun 2011-2012.

[46] Ministry of Cooperatives and SMEs Republic of Indonesia. (2015). Perkembangan data Usaha Mikro, Kecil, Menengah (UMKM) dan Usaha Besar (UB) tahun 2012-2013 [The Development of Micro, Small, Medium and Large-Sized Business, 2012-2013.

[47] OECD. (2008). Removing barriers to SME access to international markets. SecretaryGeneral of the OECD.

[48] OECD. (2009). Top barriers and drivers to SME internationalisation. The OECD Working Party on SMEs and Entrepreneurship, OECD.

[49] OECD. (2012). Fostering SMEs' participation in global markets. OECD.

[50] OECD-APEC. (2006). Removing barriers to SME access to international markets. Paper presented at the meeting of the OECD-APEC Global Conference, Athens.

[51] Onkelinx, J., \& Sleuwaegen, L. (2008). Internationalisation of SMEs. Research Report Flanders District of Creativity, 42-44. 
[52] Pendergast, W. R., Sunje, A., \& Pasic, M. (2008). The internationalization of SMEs in Bosnia and Herzegovina. In L.-P. Dana, I. M. Wellpe, M. Han \& V. Ratten (Eds.), Handbook of research on European entrepreneurship: Towards a theory of internationalization (pp. 94-113). London: Edward Elgar.

[53] Rahardhan, P., Kusumaningrum, A., \& Rahman, F. A. (2008). Pengaruh Asean trade facilitation terhadap volume perdagangan produk unggulan Jawa Timur. Study Report.

[54] Resosudarmo, I. A. P. (2004). Closer to people and trees: will decentralisation work for the people and the forests of Indonesia? The European Journal of Development Research, 16(1), 110-132.

[55] Revindo, M. D. (2017). Internationalisation of Indonesian SMEs (Doctoral dissertation). Lincoln University.

[56] Revindo, M. D. (2018). Types and severities of export barriers: Evidence from Indonesian SMEs. Economics and Finance in Indonesia, 63(2), 150-175. doi: http://dx.doi.org/10.7454/efi.v63i2.573.

[57] Revindo, M., \& Gan, C. (2016). Export stimuli, export stages and internationalization pathways: The case of Indonesian SMEs. Economics and Finance in Indonesia, 62(3), 191-205. doi: http://dx.doi.org/10.7454/efi.v62i3.557.

[58] Revindo, M. D., Gan, C., \& Nguyen, C. C. (2017). Internationalization strategy and process: Evidence from Indonesian SMEs. World Journal of Management, 8(1), 59-74.

[59] Roida, H. Y., \& Sunarjanto, N. A. (2012). Family ownership type and the international involvement of SMEs: Empirical study of agency theory in East Java Indonesia. Journal International Chinese Business Review, 11(2), 224-232.

[60] Ruzzier, M., Hisrich, R. D., \& Antoncic, B. (2006). SME internationalization research: past, present, and future. Journal of Small Business and Enterprise Development, 13(4), 476-497. doi: https:/ / doi.org/10.1108/14626000610705705.

[61] Sari, D. (2011). Internationalisation of manufacturing SMEs: The case of Indonesia. International Council for Small business (ICSB). Symposium conducted at the meeting of the International Council for Small Business (ICSB) World Conference Washington.

[62] Sari, D., Alam, Q., \& Beaumont, N. (2008). Internationalisation of SMEs in Indonesia: Entrepreneur human and social capital. Working Papers in Business, Management and Finance No. 200801. Bandung: Padjadjaran University.

[63] Tambunan, T. (2009a). Export-oriented small and medium industry clusters in Indonesia. Journal of Enterprising Communities: People and Places in the Global Economy, 3(1), 25-25. doi: 10.1108/17506200910943661.

[64] Tambunan, T. (2009b). Facilitating small and medium enterprises in international trade (export): The case of Indonesia.Paper presented at the meeting of the Asia-Pacific Trade Economists' Conference: Trade-Led Growth in Times of Crisis, Bangkok, Thailand.

[65] Uchikawa, S., \& Keola, S. (2009). Small and medium enterprises in Cambodia, Laos, and Vietnam. In Kuchiki, A. \& S. Uchikawa (eds.), Research on Development Strategies for CLMV Countries. ERIA Research Project Report 2008-5, pp.237-273. Jakarta: ERIA.

[66] UNCTAD. (2014). World investment report 2014: Investing in the SDGs: An action plan. New York and Geneva: United Nations Conference on Trade and Development. https://unctad.org/en/pages/PublicationWebflyer.aspx?publicationid=937.

[67] UNCTAD. (2015). World investment report 2015: Reforming international investment governance. New York and Geneva: United Nations Conference on Trade and Development. https://unctad.org/en/pages/PublicationWebflyer.aspx?publicationid=1245.

[68] Welch, L. S., \& Luostarinen, R. (1999). Internationalization - Evolution of a concept. 
In P. J. Buckley \& P. N. Ghauri (Eds.), The Internationalization of the firm (pp. 83-98). Oxford: Thomson Learning.

[69] Wengel, J. t., \& Rodriguez, E. (2006). SME export performance in Indonesia after the crisis. Small Business Economics, 26(1), 25-37. doi: 10.1007/s11187-004-6491-y.

[70] Wignaraja, G. (2012). Engaging small and medium enterprises in production networks: Firm-level analysis of five ASEAN economies. ADBI Working Paper Series No. 361. Asian Development Bank Institute. https:/ /www.adb.org/publications / engaging-small-and-medium-enterprises-production-networks-firm-levelanalysis-five.

[71] Wiratno, U., \& Dhewanto, W. (n.d.). Analisis Usaha Mikro, Kecil dan Menengah (UMKM): UMKM sebagai pasar potensial perbankan.

[72] Zubadi, H., \& Nugroho, W. S. (2012). Pertumbuhan usaha pada UKM di Kota Magelang. Jurnal Bisnis dan Ekonomi, 10(2), 126-139. 


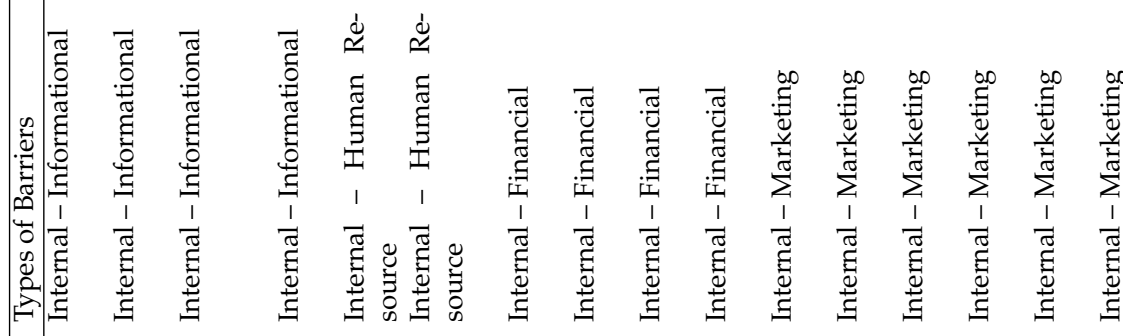

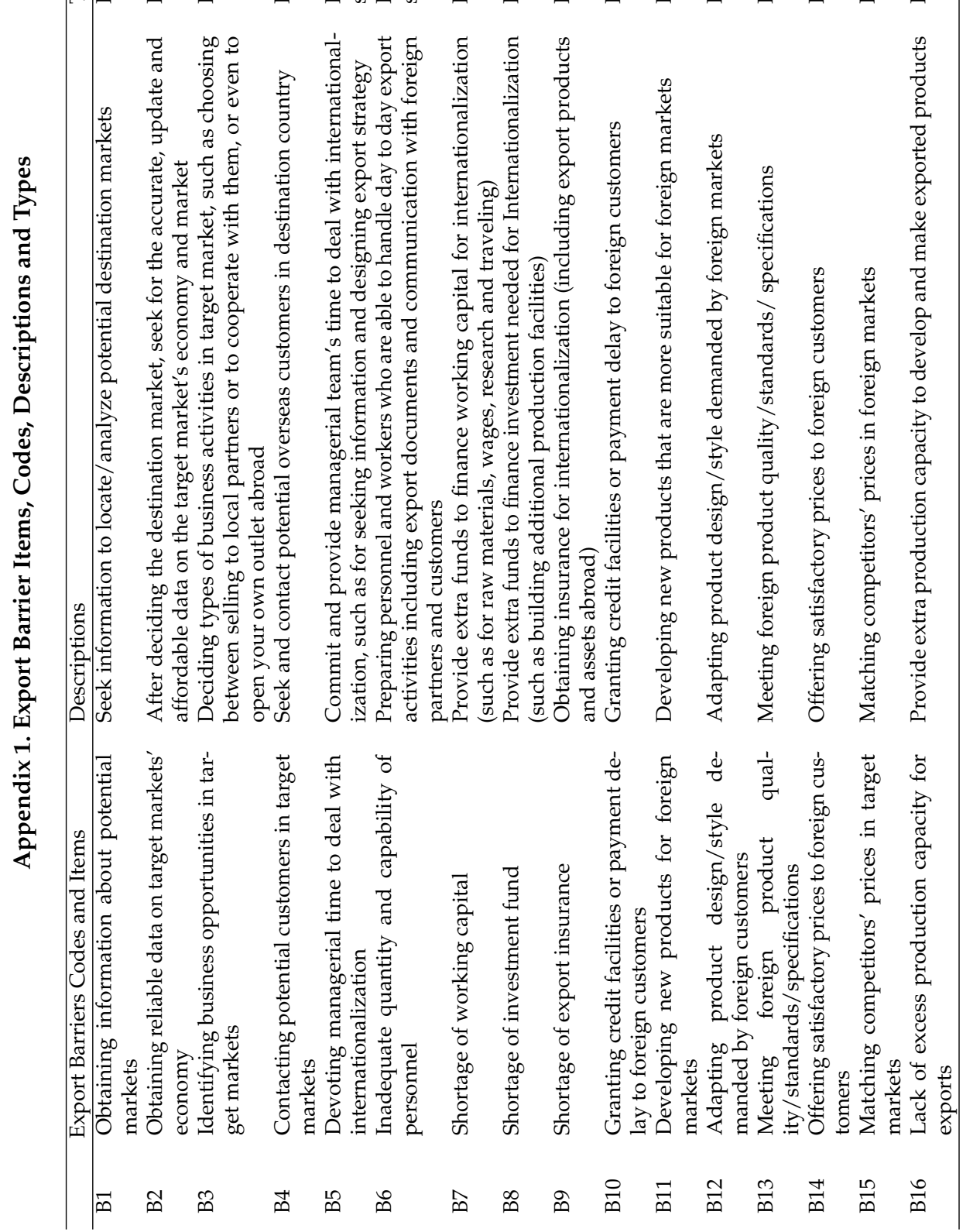




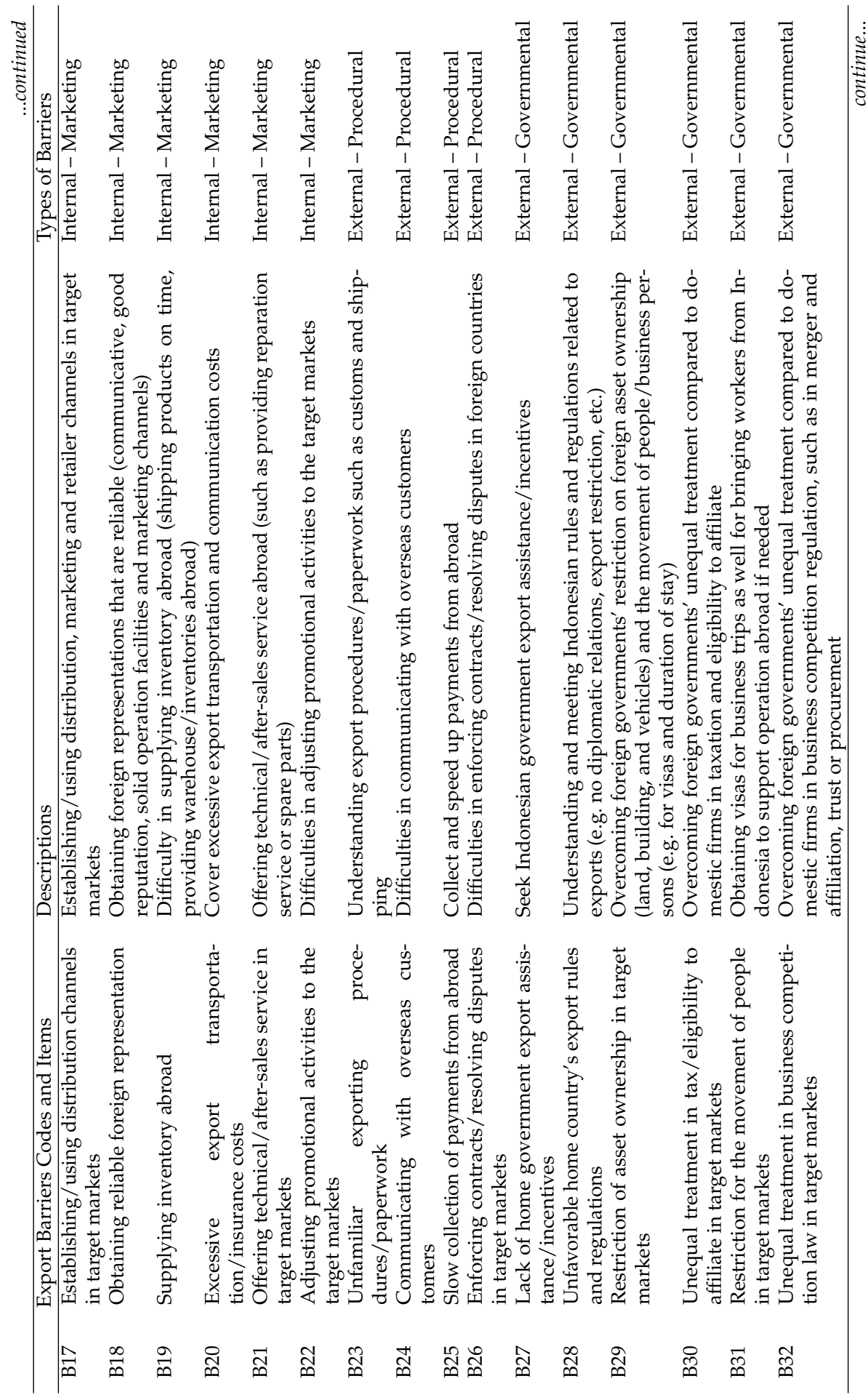




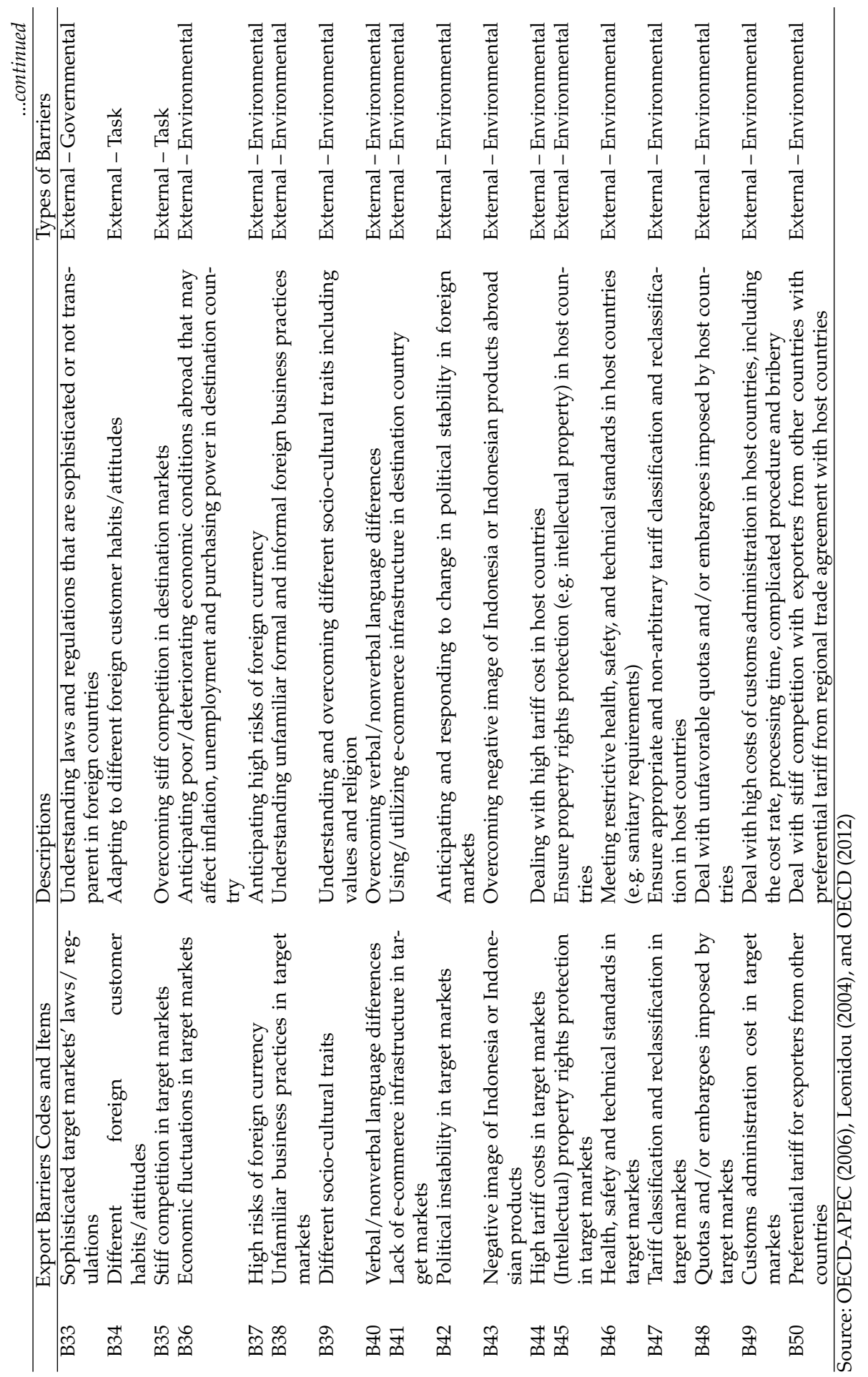




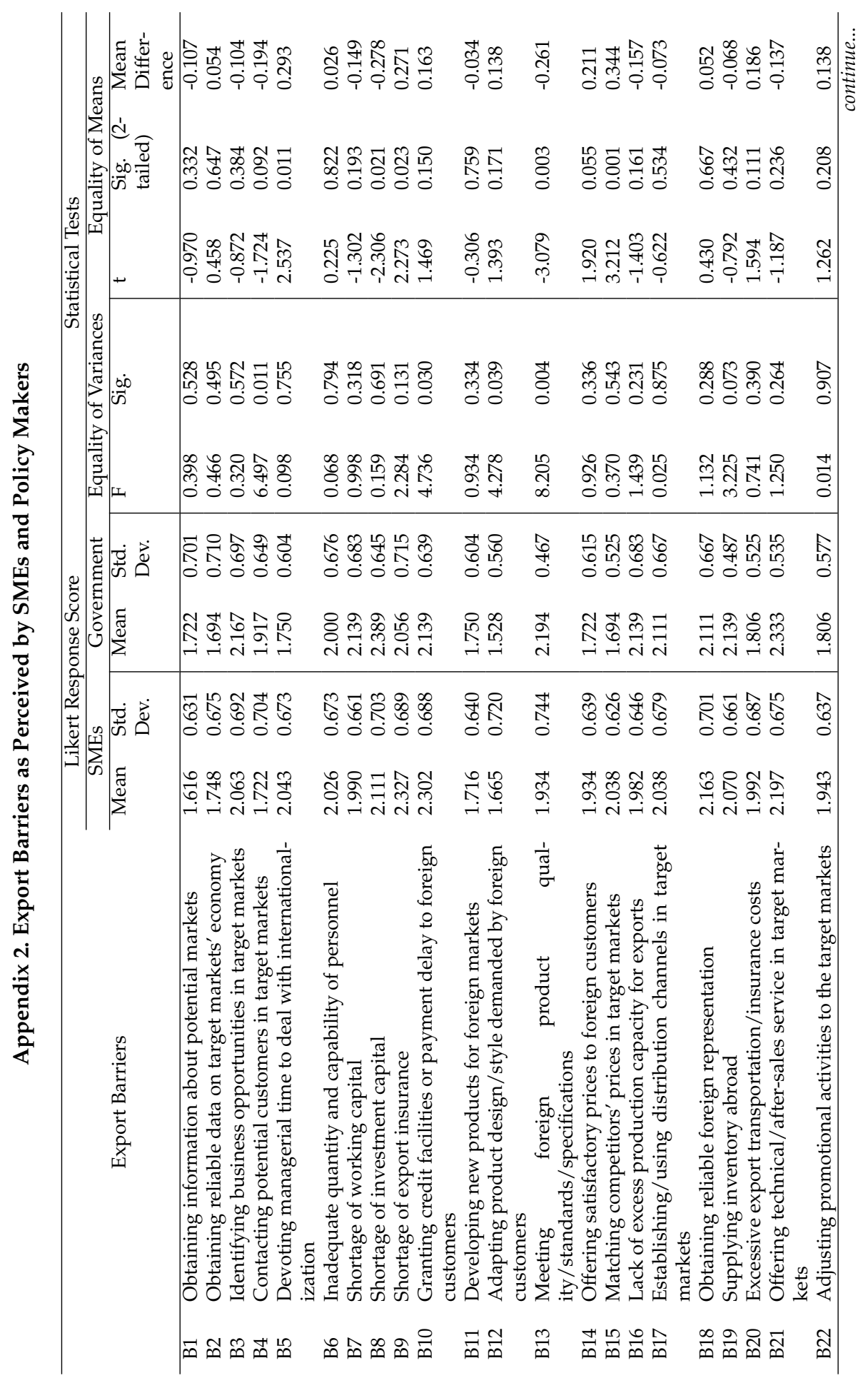




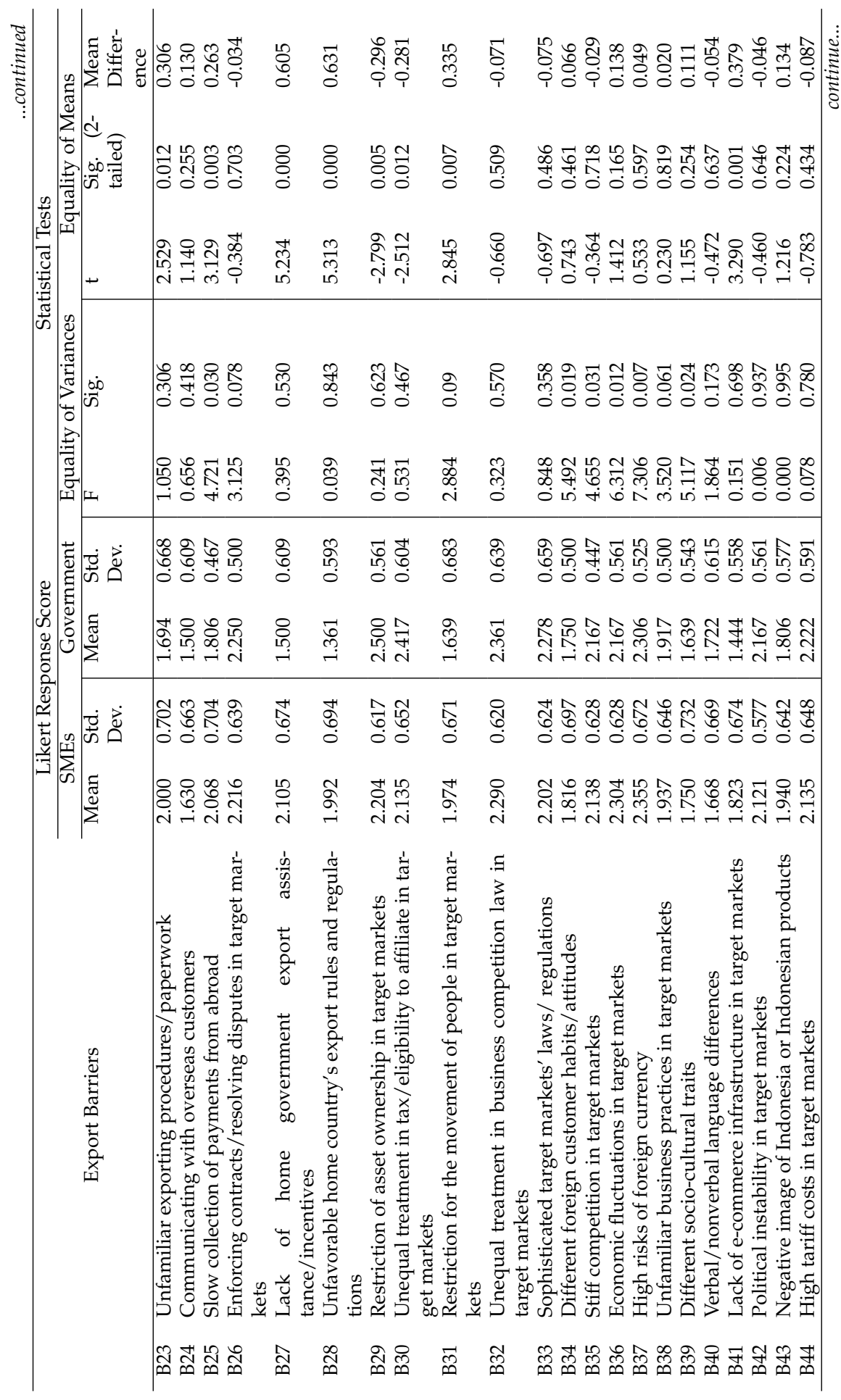




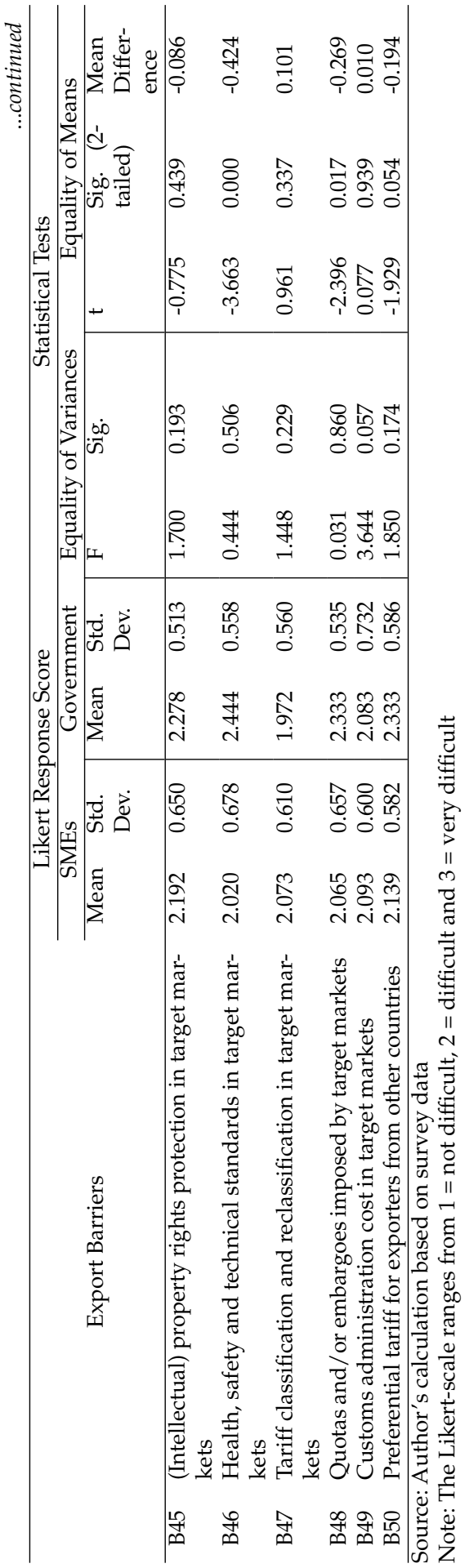


this page intentionally left blank 